\title{
TINJAUAN PENGELOLAAN SAMPAH DI OBJEK WISATA DREAM LAND WATER PARK AJIBARANG KABUPATEN BANYUMAS TAHUN 2016
}

\author{
Ogi Tri Utomo ${ }^{1)}$, Nur Hilal ${ }^{2)}$ \\ Jurusan Kesehatan Lingkungan, Politeknik Kesehatan Kemenkes Semarang, \\ Jl. Raya Baturaden KM 12 Purwokerto, Indonesia
}

\begin{abstract}
Abstrak
Berdasarkan data dari Objek Wisata Dream Land Weter Park, semakin banyak jumlah pengunjung, maka semakin banyak sampah yang dihasilkan dari aktifitas pengunjung objek wisata. Tujuan dari KTI ini adalah mengetahui tahap penimbulan sampah, pewadahan, pengumpulan, pengolahan, pemindahan dan pengangkutan. Metode penelitian yang digunakan deskriptif, yaitu untuk menjelaskan gambaran nyata tahap penimbulan sampah, pewadahan, pengumpulan, pengolahan, pemindahan dan pengangkutan. Pengumpulan data dengan cara observasi, wawancara, dan pengukuran diperoleh hasil pengelolaan sampah di objek wisata sudah baik. Hasil penelitian yang dilakukan, pengelolaan sampah dimulai dari tahap penimbulan hingga tahap pengangkutan. Tahap penimbulan, sampah dihasilkan dari aktifitas pengunjung, pedagang, kantor, dan aktifitas alam. Tempat sampah yang terdapat di objek wisata berjumlah 265 buah yang terdiri dari : fiber, tempat sampah plastik, dan logam. Volume rata-rata timbulan sampah adalah 4548 lt per hari. Tahap pengumpulan sampah di objek wisata dilakukan dengan cara memasukan sampah kedalam kantong plastik kemudian melalukan pemilahan antara sampah basah dan sampah kering sebelum diangkut ke TPS. Sampah kering (plastik, botol minuman, sterofoam) hasil pemilahan dimanfaatkan untuk dijual. Tahap akhir dari pengelolaan sampah yaitu sampah diangkut ke TPA Gunung Tugel. Kesimpulan dari penelitian yaitu pengelolaan sampah di objek wisata mulai dari tahap penimbulan hingga tahap pengangkutan. Saran agar petugas pengelolaan sampah menggunakan APD dan pemberian penutup pada alat (tempat sampah dan mobil pengangkut sampah).
\end{abstract}

Kata kunci : pengelolaan sampah di objek wisata

\section{I.PENDAHULUAN}

Dalam UU No.18 tahun 2008 tentang Pengelolaan Sampah, disebutkan sampah adalah sisa kegiatan sehari-hari manusia atau proses alam, yang berbentuk padat atau semi padat berupa zat organik dan anorganik, bersifat dapat terurai yang dianggap sudah tidak berguna lagi dan dibuang ke lingkungan.

Obyek Wisata Dream Land Water Park memiliki luas 8 Ha. Obyek wisata ini setiap hari menghasilkan sampah yang didominasi sampah organik dan anorganik sisa aktivitas wisatawan. Penanganan sampah yang terlambat menyebabkan sampah mudah menggunung di tempat penampungan sampah sementara bahkan berserakan di lingkungan obyek wisata.

Sampah di obyek wisata menjadi hal yang harus dipikirkan dan ditangani untuk menjaga eksistensi obyek wisata dan meningkatkan daya tarik wisatawan. Tujuan penelitian ini adalah untuk mengetahui tahap

1) Email : ogitri07@gmail.com

2) Email : inung.nh@gmail.com

Penelitian ini dilaksanakan di Objek Wisata Dream Land Water Park yang memiliki luas $8 \mathrm{Ha}$.

Subjek penelitian ini adalah pengelolaan sampah di Objek Wisata Dream Land Water Park Ajibarang Kabupaten Banyumas Tahun 2016. Jenis data yang dikumpulkan meliputi data umum dan data khusus. Cara pengumpulan data observasi, kuesioner, dan checklist.

Metode penelitian yang digunakan adalah deskriptif untuk memperoleh gambaran nyata tentang tahap pengelolaan sampah di objek wisata.

\section{III.HASIL DAN PEMBAHASAN}

Hasil Jumlah Pedagang

Tabel 4.1 Jumlah Pedagang Berdasarkan Jenis Dagangan di Objek Wisata Dream Land Water Park Pancasan, Ajibarang Kabupaten Banyumas Tahun 2016

\begin{tabular}{lcc}
\hline No. Jenis Barang Dagangan & $\begin{array}{c}\text { Jumlah } \\
\text { (orang) }\end{array}$ & $\begin{array}{c}\text { Prosen- } \\
\text { tasi (\%) }\end{array}$ \\
\hline 1. Soft drink, es cream, rokok & 2 & 7,14 \\
\hline 2. Kopi, jus, gorengan, aneka kue & 2 & 7,14 \\
\hline 3. Souvenir, snack & 2 & 7,14 \\
\hline 4. Pop mie & 2 & 7,14 \\
\hline 5. Mie ayam & 2 & 7,14 \\
\hline 6. Bakso & 2 & 7,14 \\
\hline 7. Sop buntut sapi & 2 & 7,14 \\
\hline 8. Nasi pecel & 2 & 7,14 \\
\hline 9. Batagor, somai & 2 & 7,14 \\
\hline 10.Pecel lele, nasi goreng & 2 & 7,14 \\
\hline
\end{tabular}




\begin{tabular}{lcc}
\hline 11.Seblak & 2 & 7,14 \\
\hline 12.Pakaian & 2 & 7,14 \\
\hline 13.Souvenir & 2 & 7,14 \\
\hline Jumlah & $\mathbf{2 8}$ & $\mathbf{1 0 0}$
\end{tabular}

Sumber : Human Resource Development (HRD)

Pedagang di Dream Land Water Park umumnya menjual makanan dan minuman. Hal ini dibuktikan dengan 13 kios yang tersedia, 11 kios diantaranya merupakan penjual makanan dan minuman.

\section{Hasil Jumlah Pengunjung}

Tabel 4.2 Jumlah Pengunjung dari Tanggal 23 Mei 29 Mei 2016 di Objek Wisata Dream Land Water Park Pancasan, Ajibarang Kabupaten Banyumas Tahun 2016

\begin{tabular}{lcc}
\hline No. Hari/ Tanggal & $\begin{array}{c}\text { Jumlah } \\
\text { (orang) }\end{array}$ & $\begin{array}{c}\text { Prosen- } \\
\text { tasi (\%) }\end{array}$ \\
\hline 1. Senin, 23 Mei 2016 & 1.788 & 10,76 \\
\hline 2. Selasa, 24 Mei 2016 & 2.151 & 12,95 \\
\hline 3. Rabu, 25 Mei 2016 & 3.011 & 18,13 \\
\hline 4. Kamis, 26 Mei 2016 & 2.228 & 13,41 \\
\hline 5. Jumat, 27 Mei 2016 & 1.215 & 7,31 \\
\hline 6. Sabtu, 28 Mei 2016 & 3.020 & 18.18 \\
\hline 7. Minggu, 29 Mei 2016 & 3.192 & 19,22 \\
\hline Jumlah & $\mathbf{1 6 . 6 0 5}$ & $\mathbf{1 0 0}$ \\
\hline
\end{tabular}

Sumber : Human Resource Development (HRD)

Jumlah pengunjung Objek Wisata Dream Land Water Park terbanyak yaitu pada hari Minggu, hal ini disebab karena merupakan hari libur. Jumlah pengunjung terbanyak yaitu 3.192 (19,22\%) dan jumlah pengunjung paling sedikit pada hari jum'at yaitu 1.215 (7.31\%)

\section{Hasil Pendapatan Karcis}

Tabel 4.3 Jumlah Pendapatan Karcis Pengunjung dari Tanggal 23 Mei - 29 Mei 2016 di Objek Wisata Dream Land Water Park Pancasan, Ajibarang Kabupaten Banyumas Tahun 2016

\begin{tabular}{|c|c|}
\hline Hari/ Tanggal & $\begin{array}{c}\text { Jumlah Pendapatan } \\
\text { Karcis Pengunjung } \\
\text { (Rp) }\end{array}$ \\
\hline 1. Senin, 23 Mei 2016 & 22.860 .000 \\
\hline 2. Selasa, 24 Mei 2016 & 34.470 .000 \\
\hline 3. Rabu, 25 Mei 2016 & 46.555 .000 \\
\hline 4. Kamis, 26 Mei 2016 & 31.420 .000 \\
\hline 5. Jumat, 27 Mei 2016 & 16.275 .000 \\
\hline 6. Sabtu, 28 Mei 2016 & 59.200 .000 \\
\hline 7. Minggu, 29 Mei 2016 & 65.080 .000 \\
\hline Jumlah & 275.860 .000 \\
\hline
\end{tabular}

Hasil pendapatan dari pengunjung selama tanggal 23 Mei - 29 Mei 2016 yaitu sebesar Rp 275.860.000.

\section{Hasil Tingkat Pendidikan Tenaga Pengelolaan Sampah}

Tabel 4.4 Jumlah Tenaga Menurut Tingkat Pendidikan di Objek Wisata Dream Land Water Park Pancasan, Ajibarang Kabupaten Banyumas Tahun 2016

\begin{tabular}{lcc}
\hline No. Tingkat Pendidikan & $\begin{array}{c}\text { Jumlah } \\
\text { (orang) }\end{array}$ & $\begin{array}{c}\text { Prosen- } \\
\text { tasi (\%) }\end{array}$ \\
\hline 1. SMA/SMK & 5 & 25 \\
\hline 2. SMP & 14 & 70 \\
\hline 3. SD & 1 & 5 \\
\hline \multicolumn{1}{c}{ Jumlah } & $\mathbf{2 0}$ & $\mathbf{1 0 0}$ \\
\hline
\end{tabular}

\section{Hasil Alat Pelindung Diri}

Tabel 4.5 Alat Pelindung Diri Pengelola Sampah di Objek Wisata Dream Land Water Park Pancasan, Ajibarang Kabupaten Banyumas Tahun 2016

\begin{tabular}{|c|c|c|}
\hline Jenis APD & Jumlah & Kondisi \\
\hline 1. Pakaian khusus pekerja & 0 & - \\
\hline 2. Sarung tangan & 20 pasang & Baik \\
\hline 3. Masker & $1 \mathrm{Box}$ & Baik \\
\hline 4. Topi & 0 & - \\
\hline 5. Sepatu Boot & 20 pasang & Baik \\
\hline 6. P3K & & \\
\hline
\end{tabular}

Alat pelindung diri tersedia dan dalam kondisi baik/layak untuk digunakan. Namun pada faktanya, pemanfaatan alat pelindung diri oleh tenaga pengelola sampah masih sangat minimal. Hal ini dikarenakan menurut tenaga pengelola sampah penggunaan APD justru merepotkan dalam melakukan aktivitas membersihkan area Objek Wisata.

\section{Pengelolaan sampah}

1. Tahap penimbulan

Sumber penimbulan sampah berasal dari aktifitas pengunjung, pedagang di area objek wisata, dan kegiatan pemeliharaan lingkungan objek wisata (pemangkasan tanaman atau aktifitas alam).

Volume sampah yang ada di Objek Wisata Dream Land Water Park Pancasan, Ajibarang Kabupaten Banyumas setiap harinya rata-rata yaitu 4.548 Lt. Jenis sampah yang dihasilkan berupa sampah basah (garbage) yaitu sisa makanan, sayuran, buah, dan daun-daunan dan sampah kering (rubbish) yaitu sampah plastik, sterofoam, kertas, botol dan kaleng.

2. Tahap pewadahan

Tabel 4.5 Jumlah Tempat Sampah Dan Kapasitas di Objek Wisata Dream Land Water Park Pancasan, Ajibarang Kabupaten Banyumas Tahun 2016

\begin{tabular}{|c|c|c|c|c|}
\hline No. Bahan & Jumlah & $\begin{array}{c}\text { Kapasitas } \\
\text { (Lt) }\end{array}$ & $\begin{array}{c}\text { Total } \\
\text { (Lt) }\end{array}$ & Kondisi \\
\hline 1. Fiber & 56 & 63,2 & $3.539,2$ & $\begin{array}{l}\text { Baik } \\
(82,14 \%) \\
\text { Cukup } \\
\text { Baik } \\
(17,86 \%)\end{array}$ \\
\hline $\begin{array}{l}\text { 2. Tempat } \\
\text { sampah } \\
\text { plastic }\end{array}$ & 178 & 24,9 & $4.432,2$ & $\begin{array}{l}\text { Baik } \\
(91.01 \%) \\
\text { Cukup } \\
\text { Baik } \\
\quad(8,99 \%)\end{array}$ \\
\hline 3. Logam & 1 & 32,9 & 32,9 & Cukup Baik \\
\hline
\end{tabular}


$\begin{array}{llll}\text { Jumlah } & 235 & 361,0 & \mathbf{8 . 0 0 4 , 3}\end{array}$

Objek Wisata Dream Land Water Park memiliki 3 jenis tempat sampah, yaitu fiber, drum dan logam. Semua tempat sampah dalam kondisi baik.

3. Tahap pengumpulan

Petugas kebersihan mengumpulkan sampah dari tempat-tempat sampah di tiap sektor dan akan dikumpulkan ke dalam kantong plastik besar dengan kapasitas \pm 240 Lt/kantong yang dibawa oleh setiap petugas kebersihan. Satu kantong plastik mampu menampung sampah sebanyak \pm 180 Lt, jumlah kantong plastik di Objek Wisata Dream Land Water Park yaitu 100 buah sehingga kapasitas sampah yang dapat dikumpulkan yaitu 18.000 Lt. Pada tahap ini dilakukan pemilahan antara sampah kering dan sampah basah.

Tabel 4.7 Jumlah Sampah Perhari di Objek Wisata Dream Land Water Park Pancasan, Ajibarang Kabupaten Banyumas Tahun 2016

\begin{tabular}{lll}
\hline No. & \multicolumn{1}{c}{ Hari/ Tanggal } & $\begin{array}{c}\text { Jumlah Sampah } \\
\text { (Lt) }\end{array}$ \\
\hline 1. & Senin, 23 Mei 2016 & 4.160 \\
\hline 2. & Selasa, 24 Mei 2016 & 4.640 \\
\hline 3. & Rabu, 25 Mei 2016 & 4.960 \\
\hline 4. & Kamis, 26 Mei 2016 & 4.800 \\
\hline 5. & Jumat, 27 Mei 2016 & 3.040 \\
\hline 6. & Sabtu, 28 Mei 2016 & 4.960 \\
\hline 7. & Minggu, 29 Mei 2016 & 4.260 \\
\hline & Jumlah & 31.840 \\
\hline
\end{tabular}
hari Mingou dengan volume 5.280 . Hal in dikarenakan jumlah pengunjung banyak yaitu 3.192 orang. Sedangkan pada hari Jumat volume sampah sedikit dengan jumlah volume 3.040 Lt dengan jumlah pengunjung 1.215 orang.

Tabel 4.8 Alat dan Sarana Kebersihan di Objek Wisata Dream Land Water Park Pancasan, Ajibarang Kabupaten Banyumas Tahun 2016

\begin{tabular}{llc}
\hline No. & \multicolumn{1}{c}{$\begin{array}{c}\text { Alat dan Sarana } \\
\text { Kebersihan }\end{array}$} & Jumlah \\
\hline 1. & Sapu lidi & 14 buah \\
\hline 2. & Pengki plastic & 15 buah \\
\hline 3. & Kain pel & 14 buah \\
\hline 4. & Kantong plastic & 100 pcs/bulan \\
\hline \multicolumn{3}{c}{ Pengamatan yang dilakukan pada tahap } \\
pengumpulan sampah diperoleh hasil sebagai \\
berikut :
\end{tabular}
a. Berupa tanah/ lahan tanpa konstruksi bak
b. Tidak terletak di daerah banjir
c. Tempat mudah dijangkau oleh petugas dan kendaraan pengangkut
d. Tidak menjadi sarang serangga dan tikus
e. Mendapat perawatan setiap 2 hari sekali (disapu dan dibersihkan).

4. Tahap pengangkutan
Volume timbulan sampah di Objek Wisata Dream Land Water Park Pancasan, Ajibarang Kabupaten Banyumas diukur dengan menggunakan kendaraan pengangkut sampah dengan kapasitas 5,25 m3 dengan hasil sampah \pm 5.250 Lt dengan 2 kali pengangkutan ke tempat pembuangan sampah sementara.

Hasil pengamatan dalam pengangkutan sampah, yaitu :

a. Tidak terdapat sampah yang berceceran sewaktu pengangkutan.

b. Petugas tidak menggunakan pakaian kerja khusus.

c. Petugas lebih sering tidak menggunakan Alat Pelindung Diri (APD) dalam bekerja.

d. Kendaraan kedap air.

e. Alat angkut dalam keadaan baik.

f. Kapasitas mencukupi.

5. Tahap pengelolaan dan pemanfaatan

Objek Wisata Dream Land Water Park Pancasan, Ajibarang Kabupaten Banyumas melakukan pemanfaatan sampah dengan menjual sampah kering dari hasil pemilahan. Hasil penjualan sampah kering (plastik, botol minuman, sterofoam, dan kardus) dikumpulkan sebagai kas oleh petugas pengelolaan sampah.

6. Tahap pembuangan akhir

Berdasarkan wawancara, Objek Wisata Dream Land Water Park bekerja sama dengan Dinas Cipta Karya dalam pembuangan sampah menuju TPA Gunung Tugel. Frekuensi pengangkutan dilakukan 2 kali seminggu pada hari Senin dan Kamis. Lokasi pembuangan sampah akhir berada di TPA Gunung Tugel.

\section{IV.KESIMPULAN}

1. Tahap penimbulan sampah di Objek Wisata Dream Land Water Park tergolong cukup baik, yaitu : sumber sampah berasal dari hari aktifitas perdagangan, pengunjung, dan karyawan, jenis sampah yang dihasilkan beragam, tidak terdapat tikus dan lalat, dan terdapat larangan membuang sampah pada tempatnya. Pada tahap ini belum ada pemisahan antara sampah organik dan sampah anorganik. Masih terdapat sampah yang berceceran di area Objek Wisata. Rata-rata volume timbulan sampah di setiap harinya adalah 4.548 lt yang berasal dari 7 sektor yang terdapat di objek wisata.

2. Tahap pewadahan di Objek Wisata dalam kategori baik. Tempat sampah berkontruksi kuat, mudah dibersihkan, mudah dikosongkan, kedap air, mudah dijangkau oleh pengunjung dan petugas serta tidak berserakan di sekitar tempat sampah. Tetapi tempat sampah tidak tertutup dan belum ada pemisahan antara sampah basah dan sampah kering.

3. Tahap pengumpulan sampah dalam kategori baik, sampah di objek wisata dikumpulkan dengan cara dimasukan kedalam kantong plastik besar. Alat 
pengumpulan yang digunakan sudah memenuhi syarat yaitu kedap air dan memiliki kapasitas yang mencukupi untuk mengumpulkan sampah. Pada tahap ini sudah ada pemilahan antara sampah basah dan juga sampah kering, namun petugas tidak menggunakan APD sehingga meningkatkan resiko penularan penyakit melalui sampah.

4. Tahap pengangkutan di objek wisata ini tergolong baik, hal ini ditunjukkan dengan tidak adanya sampah yang berceceran sewaktu pengangkutan, kendaraan kedap air, alat angkut dalam keadaan baik. Tetapi pada alat pengangkut belum dilengkapi dengan tutup (jaring/ terpal) dan petugas pengelolaan sampah tidak menggunakan APD pada saat bekerja. Hal ini beresiko penularan penyakit melalui media sampah.

5. Objek wisata Dream Land Water Park tidak melakukan pengolahan sampah secara khusus.

6. Di Objek Wisata Dream Land Water Park melakukan pemanfaatan sampah dengan menjual sampah kering (plastik, botol minuman, sterofoam, dan kardus) yang dihasilkan dari pemilahan sampah objek wisata.

7. Tahap pembuangan akhir dalam kategori tidak baik, hal ini dikarenakan terdapat lalat dan tikus, petugas tidak menggunakan APD, petugas tidak menggunakan pakaian khusus dalam bekerja, dan sampah di Objek Wisata dibuang ke TPA Gunung Tugel dengan metode open dumping. TPA ini terletak diluar wilayah Objek Wisata sehingga tidak mengganggu masyarakat sekitar, pengunjung dan karyawan.

\section{UCAPAN TERIMA KASIH}

Terima kasih disampaikan kepada Objek Wisata Dream Land Water Park Ajibarang Kabupaten Banyumas, Jurusan Kesehatan Lingkungan, dosen pembimbing KTI Politeknik Kesehatan Kemenkes Semarang serta pihak-pihak yang terkait sehingga penelitian ini dapat terlaksanakan.

\section{DAFTAR PUSTAKA}

Chandra. Budiman, Pengantar Kesehatan Lingkungan, Jakarta : Penerbit Buku Kedokteran EGC; 2007; h.111; 112; 115; 122-123

Http://id.wikipedia.org/wiki/Pengelolaan_sampah [Diakses tanggal 28 Desember 2015 pukul 16.16 WIB].

Indonesia, Departemen Kesehatan RI, Pedoman Bidang Studi Pembuangan Sampah, Jakarta : Proyek Pembangunan Pendidikan Tenaga Sanitasi Pusat; 1987; h.20; 21; 23; 31

Indonesia, Departemen Kesehatan RI, Pelatihan Pegawasan Kualitas Kesehatan Lingkungan Pemukiman, Jakarta : Departemen Kesehatan RI Direktorat Jenderal PPM dan PLP; 1996; h.27

Naltaru, Merlin. Purnaini, Rizki. Irsan, Robby. Strategi Perencanaan Sistem Pengelolaan Sampah di Kawasan Wisata Bukit Kelam Kabupaten Sintang. Jurnal Universitas Tanjungpura, 2013 [Diakses tanggal 30 Januari 2016]. Didapat dari http://jurnal.untan.ac.id

Notoatmodjo, Soekidjo.Metodologi Penelitian Kesehatan.Jakarta.Rineka Cipta; 2010; h.203

Refian, Regi. Analisis Penanganan Sampah di Objek Wisata Pantai Pangandaran Kecamatan Pangandaran Kabupaten Ciamis. Jurnal Universitas Galuh 2013 [Diakses tanggal 30 Januari 2016]. Didapat darihttp://docfoc.com

Sahwan, Firman. Strategi Pengolahan Sampah di Kawasan Kepulauan Seribu. Jurnal Penelitian 2004 [Diakses tanggal 30 Januari 2016]. Didapat dari http://ejurnal.bppt.go.id

Santdjaka, Aris, Bio Statistik, Purwokerto: Politeknik Kesehatan Kemenkes Semarang Jurusan Kesehatan Lingkungan; 2008 